\title{
GC-MS Headspace Analysis of Terminalia ferdinandiana fruit and Leaf Extracts which inhibit Bacillus anthracis Growth
}

\author{
Mitchell Henry Wright ${ }^{1}$, Joseph Sirdaarta ${ }^{1,2}$, Alan White ${ }^{1}$, Anthony Carlson Greene ${ }^{1}$, lan Edwin Cock ${ }^{1,2}$
}

\section{Mitchell Henry Wright ${ }^{1}$, Joseph Sirdaarta ${ }^{1,2}$, Alan White ${ }^{1}$, Anthony Carlson Greene $^{1}$, Ian Edwin Cock ${ }^{1,2}$ \\ 'School of Natural Sciences, Nathan Campus, Griffith University, Brisbane, Australia \\ ${ }^{2}$ Environmental Futures Research Institute, Nathan Campus, Griffith University, Brisbane, Australia \\ Correspondence}

Ian Edwin Cock, School of Natural Sciences, Nathan Campus, Griffith University, Brisbane, Australia

Tel.: +61 737357637 ;

fax: +61737355282 .

E-mail: I.Cock@griffith.edu.au (I. E. Cock) History

- Submission Date: 20-06-2016;

- Review completed: 16-08-2016;

- Accepted Date: 05-09-2016.

DOI : 10.5530/pj.2017.1.14

Article Available online

http://www.phcogj.com/v9/i1

\section{Copyright}

(C) 2016 Phcog.Net. This is an openaccess article distributed under the terms of the Creative Commons Attribution 4.0 International license.

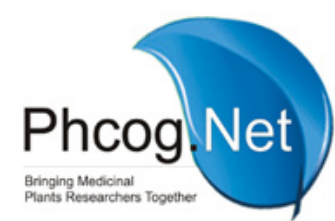

\begin{abstract}
Background: Terminalia ferdinandiana (Kakadu plum) is an endemic Australian plant with an extremely high antioxidant capacity. The fruit has long been used by the first Australians as a nutritional food and as a medicine and recent studies have reported its potent growth inhibitory activity against a broad panel of bacteria. Despite this, $T$. ferdinandiana extracts are yet to be tested for the ability to inhibit the growth of Bacillus anthracis. Materials and Methods: Solvent extracts were prepared using both the fruit and leaf of Kakadu plum. The ability to inhibit the growth of $B$. anthracis was investigated using a disc diffusion assay. Their MIC values were determined to quantify and compare their efficacies. Toxicity was determined using the Artemia franciscana nauplii bioassay. The most potent extracts were investigated using non-targeted GCMS head space analysis (with screening against a compound database) for the identification and characterisation of individual components in the crude plant extracts. Results: Solvent extractions of T. ferdinandiana fruit and leaf displayed good growth inhibitory activity in the disc diffusion assay against $B$. anthracis. Fruit ethyl acetate and methanolic leaf extracts were particularly potent growth inhibitors, with MIC values of 451 and $377 \mu \mathrm{g} / \mathrm{mL}$ respectively. The fruit methanolic and chloroform extracts, as well as the aqueous leaf extracts also were good inhibitors of $B$. anthracis growth, albeit with lower efficacy (MIC values of 1800 and $1414 \mu \mathrm{g} / \mathrm{mL}$ respectively). The aqueous fruit extract and leaf chloroform extracts had only low inhibitory activity. All other extracts were completely devoid of growth inhibitory activity. Furthermore, all of the extracts with growth inhibitory activity were nontoxic in the Artemia fransiscana bioassay, with $\mathrm{LC}_{50}$ values $>1000 \mu \mathrm{g} / \mathrm{mL}$. Non-biased GC-MS phytochemical analysis of the most active extracts (fruit ethyl acetate and methanolic leaf) putatively identified and highlighted several compounds that may contribute to the ability of these extracts to inhibit the growth of $B$. anthracis. Conclusions: The low toxicity of the $T$. ferdinandiana fruit ethyl acetate and methanolic leaf extracts, as well as their potent growth inhibitory bioactivity against $B$. anthracis, indicates their potential as medicinal agents in the treatment and prevention of anthrax.
\end{abstract}

Key words: Bacillus anthracis, Anthrax, Kakadu plum, Zoonotic, Tannin, Combretastatin, stilbene, Metabolomics.

\section{INTRODUCTION}

Zoonotic infections are diseases that can be transmitted indirectly or directly between humans and animals and are a significant burden from both health and economic standpoints. ${ }^{1}$ These diseases can be spread to humans from both domesticated and wild animals and can be transferred through direct contact, the contamination of drinking water by animal secretions, or the consumption of contaminated meat products. ${ }^{2}$ These diseases pose an exceptional set of problems in the control and treatment of infections, as the traditionally effective strategies of herd immunity and isolation of infected individuals are not feasible. Furthermore, unlike humans who can verbalise otherwise indistinguishable symptoms, infected animals may go unnoticed and further contribute to the spread of disease. From 1940 to 2004, approximately $60 \%$ of all emerging infectious diseases were of a zoonotic nature with the majority originating in wildlife. $^{3}$ Therefore, the development of cross species treatments plays a key role in the effective control and eradication of zoonotic diseases.

Bacillus anthracis, the etiological agent of anthrax, is a sporulating gram-positive bacterium found predominately in soils. ${ }^{4}$ Similar to other organisms within the Bacillus genus, B. anthracis is capable of producing endospores that can remain dormant for several years until conditions are again favourable for growth. These spores are metabolically inactive and are capable of surviving environmental conditions that would kill vegetative cells, including
Cite this article : Wright MH, Sirdaarta J, White A, Greene CA, Cock IE. GC-MS headspace analysis of Terminalia ferdinandiana fruit and leaf extracts which inhibit Bacillus anthracis growth. Pharmacog J. 2017;9(1):73-82. 
temperature, desiccation and enzymatic destruction. ${ }^{5}$ Although the vegetative $B$. anthracis cells produce the toxins associated with the disease, infection is generally initiated when spores are introduced into a host through inhalation, ingestion or via direct contact with open wounds. Once internalised, the spores revert to viable cells, proliferate and begin producing the deadly anthrax toxins. ${ }^{6}$ The disease has been controlled to varying degrees internationally through careful monitoring and strong eradication measures. However, anthrax is endemic worldwide and is often fatal if infection occurs. ${ }^{\text {? }}$

Current strategies in the treatment of anthrax typically involve a combination of antibiotic therapies to fight infection, as well as supportive care to manage associated symptoms. ${ }^{8}$ The administration of intravenous or oral antibiotics are generally effective in the management of anthrax, however there is always an inherent risk that the bacteria may develop drug resistance. As such, the discovery of new drugs is of significant importance, either through the design and synthesis of new compounds, or through the investigation of antimicrobials within pre-existing natural assets. ${ }^{5,9}$ The antimicrobial effects of medicinal plants have long been recognised by many cultures and phytochemical analysis to identify the active compounds offers promise in the development of new anti- $B$. anthracis agents. Thus the investigation of natural assets provides great potential in the discovery of compounds effective in managing anthrax.

Terminalia ferdinandiana, commonly referred to as Kakadu plum, is a small flowering tree endemic to the tropical northern regions of Australia. It has been used as a source of food by the first Australians for thousands of years. ${ }^{10}$ The fruit has a remarkably high antioxidant capacity and has been defined as one of the best sources of vitamin $\mathrm{C}$ of any plant in the world. ${ }^{10,11}$ The medicinal benefits of the fruit were well known by the first Australians who considered the plum both a medicine and a food source. It has been proposed that the health benefits may stem from one or many antimicrobial compounds. ${ }^{12}$ These include flavonols, flavonones, as well as benzoic acid, gallic acid and ellagic acid derivatives, all of which have been previously associated with microbial inhibition. ${ }^{13}$ Indeed, the antiseptic potential of both the fruit and leaves is well documented in the prevention of several disease-causing microorganisms ${ }^{14-17}$ and it is likely that Kakadu plum may have inhibitory compounds that aid in the prevention of $B$. anthracis growth. The current study investigates both the fruit and leaf components of T. ferdinandiana for the ability to inhibit the proliferation of vegetative $B$. anthracis cells as a natural alternative in the treatment of anthrax.

\section{MATERIALS AND METHODS}

\section{Plant source and extraction}

T. ferdinandiana fruit pulp and leaves were supplied and verified by David Boehme of Wild Harvest, Northern Territory (Australia). The pulp was frozen for transport and kept at $-10^{\circ} \mathrm{C}$ until processed. A voucher specimen of the pulp (KP2014GD) is stored at Griffith University. The leaves were thoroughly dehydrated in a Sunbeam food dehydrator and the dried material was subsequently stored at $-30^{\circ} \mathrm{C}$. A voucher specimen (KP2015LA) is stored at the School of Natural Sciences, Griffith University. Prior to use, the plant materials were thoroughly dried and ground into a coarse powder. A mass of $1 \mathrm{~g}$ of ground powder was extracted extensively in $50 \mathrm{~mL}$ of either methanol, deionised water, ethyl acetate, chloroform or hexane for $24 \mathrm{~h}$ at $4^{\circ} \mathrm{C}$ with gentle shaking. All solvents were supplied by Ajax (AR grade). The extracts were filtered through filter paper (Whatman No. 54) and air dried at room temperature. The aqueous extract was lyophilised by rotary evaporation in an Eppendorf concentrator 5301. The resultant pellets were dissolved in $10 \mathrm{~mL}$ deionised water (containing $0.5 \% \mathrm{DMSO}$ ). The extract was passed through a $0.22 \mu \mathrm{m}$ filter (Sarstedt) and stored at $4^{\circ} \mathrm{C}$.

\section{Qualitative phytochemical studies}

Phytochemical analysis of the extracts for the presence of alkaloids, anthraquinones, cardiac glycosides, flavonoids, phenolic compounds, phytosteroids, saponins, tannins and triterpenoids were conducted by previously described assays. ${ }^{18-20}$

\section{Antioxidant capacity}

The antioxidant capacity of each sample was assessed using the DPPH free radical scavenging method with modifications. ${ }^{21-23}$ Ascorbic acid (0-25 $\mu$ g per well) was used as a reference and the absorbances were recorded at $515 \mathrm{~nm}$. All tests were completed alongside controls on each plate and all were performed in triplicate. The antioxidant capacity based on DPPH free radical scavenging ability was determined for each extract and expressed as $\mu \mathrm{g}$ ascorbic acid equivalents per gram of original plant material extracted.

\section{Antibacterial screening Environmental Bacillus anthracis screening}

An environmental strain of Bacillus anthracis was isolated as previously described $^{5}$. All growth studies were performed using a modified peptone/yeast extract (PYE) agar: $1 \mathrm{~g} / \mathrm{L}$ peptone, $1.5 \mathrm{~g} / \mathrm{L}$ yeast extract, $7.5 \mathrm{~g} / \mathrm{L} \mathrm{NaCl}, 1 \mathrm{~g} / \mathrm{L}$ ammonium persulfate, $2.4 \mathrm{~g} / \mathrm{L}$ HEPES buffer $(\mathrm{pH} 7.5)$ and $16 \mathrm{~g} / \mathrm{L}$ bacteriological agar when required. Incubation was at $30^{\circ} \mathrm{C}$ and the stock culture was subcultured and maintained in PYE media at $4^{\circ} \mathrm{C}$. The media nutrient components were supplied by Oxoid Ltd. The Gen Bank accession number for the 16S rRNA gene sequence for the isolate is KR003287.

\section{Evaluation of antimicrobial activity}

Antimicrobial activity of all plant extracts was determined using a modified disc diffusion assay. ${ }^{24-26}$ Briefly, $100 \mu \mathrm{L}$ of the test bacterium was grown in $10 \mathrm{~mL}$ of fresh nutrient broth media until they reached a count of $\sim 10^{8}$ cells $/ \mathrm{mL}$. A volume of $100 \mu \mathrm{L}$ of the bacterial suspension was spread onto nutrient agar plates and extracts were tested for antibacterial activity using $5 \mathrm{~mm}$ sterilised filter paper discs. Discs were impregnated with $10 \mu \mathrm{L}$ of the test sample, allowed to dry and placed onto the inoculated plates. The plates were allowed to stand at $4^{\circ} \mathrm{C}$ for $2 \mathrm{~h}$ before incubation at $30^{\circ} \mathrm{C}$ for $24 \mathrm{~h}$. The diameters of the inhibition zones were measured to the closest whole millimetre. Each assay was performed in at least triplicate. Mean values $( \pm$ SEM) are reported in this study. Standard discs of penicillin $(2 \mu \mathrm{g})$ and ampicillin $(10 \mu \mathrm{g})$ were obtained from Oxoid Ltd. and used as positive controls for antibacterial activity. Filter discs impregnated with $10 \mu \mathrm{L}$ of distilled water were used as a negative control.

\section{Minimum inhibitory concentration (MIC) determination}

The minimum inhibitory concentrations (MIC) of the extracts was determined as previously described ${ }^{27}$. Briefly, the plant extracts were diluted in deionised water and tested across a range of concentrations. Discs were impregnated with $10 \mu \mathrm{L}$ of the extract dilutions, allowed to dry and placed onto inoculated plates. The assay was performed as outlined above and graphs of the zone of inhibition versus concentration were plotted. MIC values were determined using linear regression.

\section{Toxicity screening \\ Reference toxin for toxicity screening}

Potassium dichromate $\left(\mathrm{K}_{2} \mathrm{Cr}_{2} \mathrm{O}_{7}\right)$ (AR grade, Chem-Supply, Australia) was prepared in distilled water $(4 \mathrm{mg} / \mathrm{mL})$ and serially diluted in artificial seawater for use in the Artemia franciscana nauplii bioassay. 


\section{Artemia franciscana nauplii toxicity screening}

Toxicity was tested using a modified $A$. franciscana nauplii lethality assay. ${ }^{28-30}$ Briefly, $400 \mu \mathrm{L}$ of seawater containing approximately 43 (mean $43.2, \mathrm{n}=155, \mathrm{SD} 14.5)$ A. franciscana nauplii were added to wells of a 48 well plate and immediately used in the bioassay. A volume of $400 \mu \mathrm{L}$ of reference toxin or the diluted plant extracts were transferred to the wells and incubated at $25 \pm 1^{\circ} \mathrm{C}$ under artificial light (1000 Lux). A negative control $(400 \mu \mathrm{L}$ seawater $)$ was run in triplicate for each plate. All treatments were performed in at least triplicate. The wells were checked at regular intervals and the number of dead counted. The nauplii were considered dead if no movement of the appendages was observed within 10 seconds. After $24 \mathrm{~h}$, all nauplii were sacrificed and counted to determine the total $\%$ mortality per well. The $\mathrm{LC}_{50}$ with $95 \%$ confidence limits for each treatment was calculated using probit analysis.

\section{Non-targeted GC-MS head space analysis}

Separation and quantification were performed using a Shimadzu GC-2010 plus (USA) linked to a Shimadzu MS TQ8040 (USA) mass selective detector system as previously described..$^{15}$ Briefly, the system was equipped with a Shimadzu auto-sampler AOC-5000 plus (USA) fitted with a solid phase micro-extraction fibre (SPME) handling system utilising a Supelco (USA) divinyl benzene/carbowax/polydimethylsiloxane (DVB/CAR/PDMS). Chromatographic separation was accomplished using a 5\% phenyl, 95\% dimethylpolysiloxane ( $30 \mathrm{~m}$ x0.25 $\mathrm{mm}$ id x $0.25 \mathrm{um}$ ) capillary column (Restek USA). Helium (99.999\%) was employed as a carrier gas at a flow rate of $0.79 \mathrm{ml} / \mathrm{min}$. The injector temperature was set at $230^{\circ} \mathrm{C}$. Sampling utilised a SPME cycle which consisted of an agitation phase at $500 \mathrm{rpm}$ for a period of $5 \mathrm{sec}$. The fibre was exposed to the sample for $10 \mathrm{~min}$ to allow for absorption and then desorbed in the injection port for $1 \mathrm{~min}$ at $250^{\circ} \mathrm{C}$. The initial column temperature was held at $30^{\circ} \mathrm{C}$ for $2 \mathrm{~min}$, increased to $140^{\circ} \mathrm{C}$ for $5 \mathrm{~min}$, then increased to $270^{\circ} \mathrm{C}$ over a period of $3 \mathrm{mins}$ and held at that temperature for the duration of the analysis. The GC-MS interface was maintained at $200^{\circ} \mathrm{C}$ with no signal acquired for a min after injection in split-less mode. The mass spectrometer was operated in the electron ionisation mode at $70 \mathrm{eV}$. The analytes were then recorded in total ion count (TIC) mode. The TIC was acquired after a min and for duration of 45 mins utilising a mass range of $45-450 \mathrm{~m} / \mathrm{z}$.

\section{Statistical analysis}

Data is expressed as the mean \pm SEM of at least three independent experiments.

\section{RESULTS}

\section{Liquid extraction yields and qualitative phytochemical screening}

Extractions of the various dried Kakadu plum plant materials ( $1 \mathrm{~g}$ ) with various solvents yielded dried plant extracts ranging from $18 \mathrm{mg}$ (hexane fruit extract) to $483 \mathrm{mg}$ (aqueous fruit extract) (Table 1). Methanolic and aqueous extracts gave significantly higher yields of dried extracted material compared to the chloroform, hexane and ethyl acetate counterparts, which gave low to moderate yields. The dried extracts were resuspended in $10 \mathrm{~mL}$ of deionised water (containing $1 \% \mathrm{DMSO}$ ), resulting in the extract concentrations shown in Table 1.

\section{Antimicrobial activity}

To determine the ability of the crude plant extracts to inhibit the growth of $B$. anthracis, aliquots $(10 \mu \mathrm{L})$ of each extract were screened using a disc diffusion assay. The bacterial growth was strongly inhibited by 7 of the 10 extracts screened (70\%) (Figure 1). The methanolic leaf extract

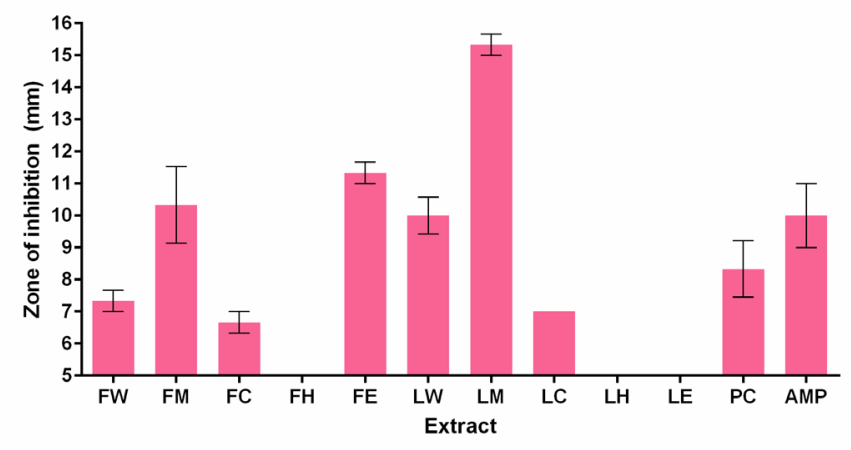

Figure 1: Growth inhibitory activity of Kakadu plum plant extracts against the $B$. Anthracis environmental isolate measured as zones of inhibition ( $\mathrm{mm}$ ). $\mathrm{FW}=$ aqueous Kakadu plum fruit extract; $\mathrm{FM}=$ methanolic Kakadu plum fruit extract; $\mathrm{FC}=$ chloroform Kakadu plum fruit extract; $\mathrm{FH}=$ hexane Kakadu plum fruit extract; $\mathrm{FE}$ = ethyl acetate Kakadu plum fruit extract; $\mathrm{LW}=$ aqueous Kakadu plum leaf extract; $L M=$ methanolic Kakadu plum leaf extract; $\mathrm{LC}=$ chloroform Kakadu plum leaf extract; $\mathrm{LH}=$ hexane Kakadu plum leaf extract; $L E=$ ethyl acetate Kakadu plum leaf extract; $P C=$ penicillin $(2 \mu \mathrm{g})$; $\mathrm{AMP}=$ ampicillin $(10 \mu \mathrm{g})$. Results are expressed as mean zones of inhibition \pm SEM.

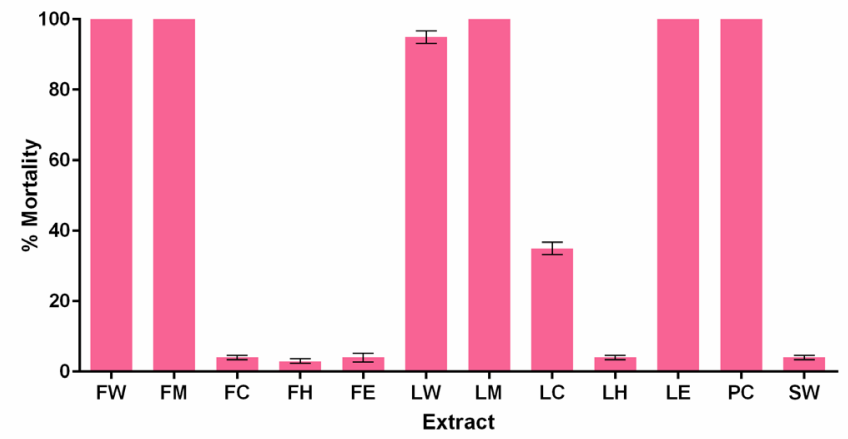

Figure 2: The lethality of the Australian plant extracts $(2000 \mu \mathrm{g} / \mathrm{mL})$ and the potassium dichromate control $(1000 \mu \mathrm{g} / \mathrm{mL})$ towards Artemia franciscana nauplii after $24 \mathrm{~h}$ exposure. $\mathrm{FW}$ = aqueous Kakadu plum fruit extract; $\mathrm{FM}=$ methanolic Kakadu plum fruit extract; $\mathrm{FC}=$ chloroform Kakadu plum fruit extract; $\mathrm{FH}=$ hexane Kakadu plum fruit extract; $\mathrm{FE}=$ ethyl acetate Kakadu plum fruit extract; $\mathrm{LW}=$ aqueous Kakadu plum leaf extract; $\mathrm{LM}=$ methanolic Kakadu plum leaf extract; $\mathrm{LC}=$ chloroform Kakadu plum leaf extract; $\mathrm{LH}=$ hexane Kakadu plum leaf extract; $\mathrm{LE}=$ ethyl acetate Kakadu plum leaf extract; $\mathrm{PC}=$ potassium dichromate control; $\mathrm{SW}=$ seawater control. Results are expressed as mean \% mortality \pm SEM.

was the most potent inhibitor of $B$. anthracis growth (as judged by zone of inhibition), with inhibition zones of $15.3 \pm 0.6 \mathrm{~mm}$. This compares favourably with the penicillin $(2 \mu \mathrm{g})$ and ampicillin controls $(10 \mu \mathrm{g})$, with zones of inhibition of $8.3 \pm 0.6$ and $10.0 \pm 0.7$ respectively. The methanolic fruit extract as well as the ethyl acetate and aqueous leaf extracts also displayed good inhibition of $B$. anthracis growth, with $\geq 8 \mathrm{~mm}$ zones of inhibition. In general, the leaf extracts were more potent inhibitors of $B$. anthracis growth than were their fruit extract counterparts.

The antimicrobial efficacy was further quantified through the determination of MIC values against the Kakadu plum extracts (Table 2). Most of the extracts were effective at inhibiting B. anthracis growth, with MIC values $<1000 \mu \mathrm{g} / \mathrm{ml}$ for several extracts $(<10 \mu \mathrm{g}$ impregnated in the disc). The ethyl acetate fruit extract and the methanolic leaf extract were particularly potent, with MIC values of $451 \mu \mathrm{g} / \mathrm{mL}$ (approximately $4.5 \mu \mathrm{g}$ infused into the disc) and $377 \mu \mathrm{g} / \mathrm{mL}$ (approximately $3.8 \mu \mathrm{g}$ infused into 


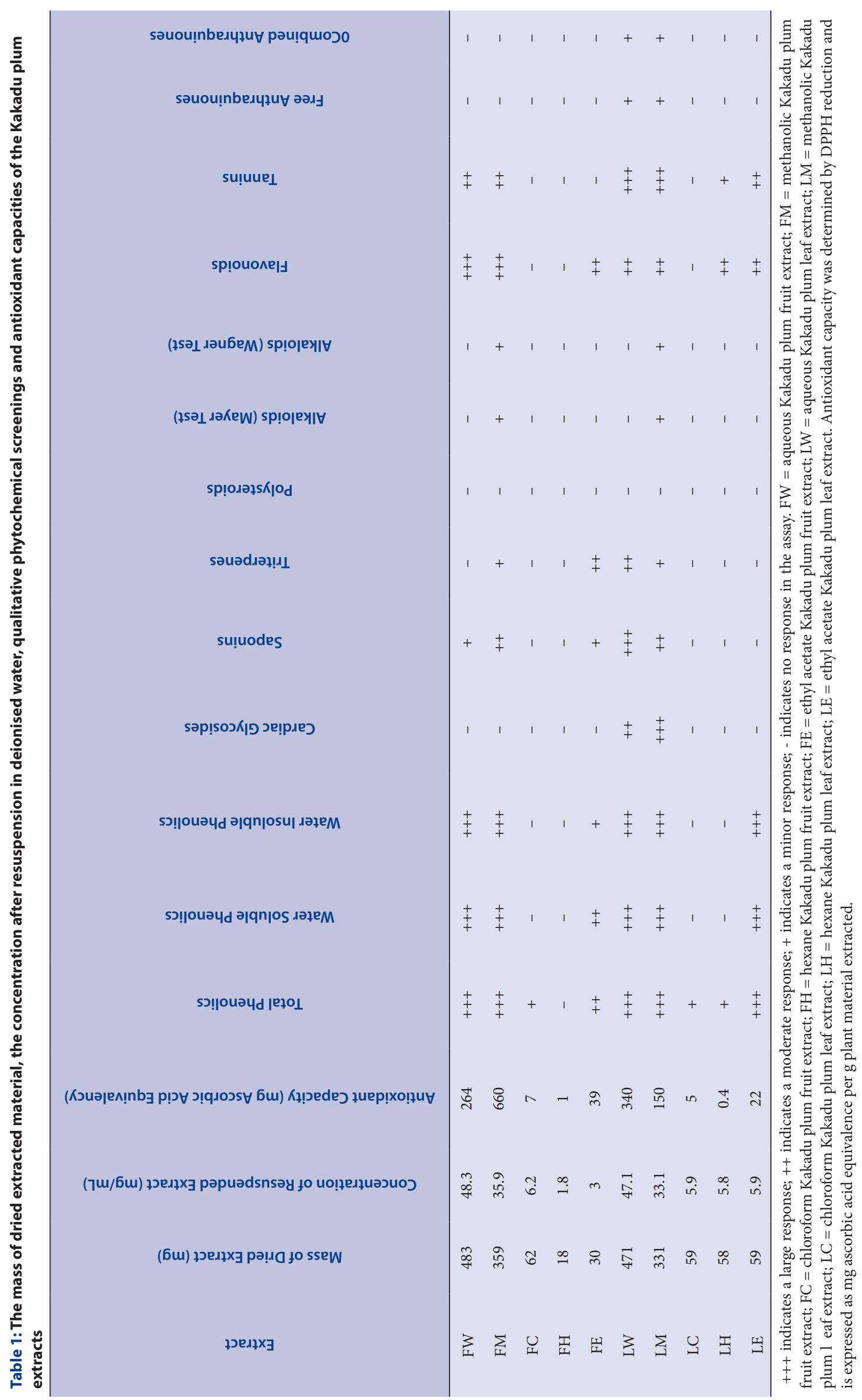


Table 2: Minimum inhibitory concentration $(\mu \mathrm{g} / \mathrm{mL})$ of the Kakadu plum fruit and leaf extracts and $\mathrm{LC}_{50}$ values $(\mu \mathrm{g} / \mathrm{mL})$ in the Artemia nauplii bioassay.

\begin{tabular}{ccc}
\hline Extract & MIC & LC $_{50}$ \\
\hline aqueous fruit extract & $>10,000$ & 2,080 \\
methanolic fruit extract & 877 & 2,115 \\
chloroform fruit extract & 1800 & - \\
hexane fruit extract & - & - \\
ethyl acetate fruit extract & 451 & - \\
aqueous leaf extract & 1414 & 1,330 \\
methanolic leaf extract & 377 & 1,133 \\
chloroform leaf extract & 5,000 & - \\
hexane leaf extract & - & - \\
ethyl acetate leaf extract & - & 767 \\
\hline
\end{tabular}

Numbers indicate the mean MIC and $\mathrm{LC}_{50}$ values of triplicate determinations. - indicates no inhibition.

the disc) respectively. These results compare well with the growth inhibitory activity of the penicillin and ampicillin controls which were tested at $2 \mu \mathrm{g}$ and $10 \mu$ grespectively. The methanolic fruit extract was also a potent $B$. anthracis growth inhibitor (MIC value of $877 \mu \mathrm{g} / \mathrm{ml}$ ). Whilst less potent, the fruit chloroform and aqueous leaf extracts also had good growth inhibitory activity (MIC values of 1800 and $1414 \mu \mathrm{g} / \mathrm{ml} \mathrm{respec-}$ tively). In contrast, the aqueous fruit and hexane extracts, as well as the leaf chloroform hexane and ethyl acetate extracts, were not active, or were of only low efficacy in the assay.

\section{Quantification of toxicity}

All extracts were initially screened at $2000 \mu \mathrm{g} / \mathrm{mL}$ in the assay (Figure 2). For comparison, the reference toxin potassium dichromate $(1000 \mu \mathrm{g} / \mathrm{mL})$ was also tested in the bioassay. The potassium dichromate reference toxin was rapid in its onset of mortality, inducing nauplii death within the first $3 \mathrm{~h}$ of exposure and $100 \%$ mortality was evident following $4-5 \mathrm{~h}$ (results not shown). All methanolic and aqueous extracts showed $>90 \%$ mortality rates at $24 \mathrm{~h}$, as did the ethyl acetate leaf extract. The remainder of the extracts showed $<10 \%$ mortality rates at $24 \mathrm{~h}$, with the exception of the chloroform leaf extract.

To further quantify the effect of toxin concentration on the induction of mortality, the extracts were serially diluted inartificial seawater to test across a range of concentrations in the Artemia nauplii bioassay at 24 hours. Table 2 shows the $\mathrm{LC}_{50}$ values of the Kakadu plum extracts towards $A$. franciscana. No $\mathrm{LC}_{50}$ values are reported for either of the chloroform and hexane extracts, nor for the ethyl acetate fruit extract, as less than $50 \%$ mortality was seen for all concentrations tested. Extracts with an $\mathrm{LC}_{50}$ greater than $1000 \mu \mathrm{g} / \mathrm{ml}$ towards Artemia nauplii have been defined as being nontoxic in this assay. ${ }^{31}$ As only the ethyl acetate fruit extract had $\mathrm{LC}_{50}<1000 \mu \mathrm{g} / \mathrm{ml}$, all other extracts were considered nontoxic. Whilst the $\mathrm{LC}_{50}$ value for leaf ethyl acetate extract is below $1000 \mu \mathrm{g} / \mathrm{ml}$, the value of $767 \mu \mathrm{g} / \mathrm{ml}$ indicates low to moderate toxicity.

\section{Non-targeted GC-MS headspace analysis of Kakadu plum extracts}

As the fruit ethyl acetate and methanolic leaf extracts had the greatest growth inhibitory efficacy against $B$. anthracis (as determined by MIC;
Table 2), they were deemed the most promising extracts for further phytochemical analysis. Optimised GC-MS parameters were developed and used to examine the phytochemical composition of these extracts. The resultant gas chromatograms for the fruit ethyl acetate and methanolic leaf extracts are presented in Figures 3 and 4 respectively. Several major peaks were noted in the fruit ethyl acetate extract at approximately 15.1 (3,3-dimethyl-hexane, 7.1\% relative abundance), 19.7 (2-methyl2-phenyl-oxirane, $14.6 \%$ relative abundance), 20.9 (m-di-tert-butylbenzene, $22 \%$ relative abundance) and $28.9 \mathrm{~min}$ (3,5-bis(1,1-dimethylethyl)phenol, $19.4 \%$ relative abundance). Numerous overlapping peaks were also evident in the middle stages of the chromatogram from 10-25 min. In total, 42 unique mass signals were noted for the T. ferdinandiana fruit ethyl acetate extract (Table 3). Putative empirical formulas and identifications were achieved for all of these compounds.

The gas chromatogram for the methanolic leaf extract (Figure 4) had substantially fewer peaks evident than the fruit ethyl acetate extract (Figure 3). In total, 19 unique mass signals were noted in themethanolic leaf extract chromatogram. Several major peaks were present at approximately 11.3 (methoxy-phenyl-oxime, 22.7\% relative abundance), 13.7 (1-octen-3-ol, $2.4 \%$ relative abundance),14.4 (2-(1,1-dimethylethoxy)ethanol, 27.7\% relative abundance), 19.5 (2-methyl-2-phenyl-oxirane, $11.4 \%$ relative abundance) and $21.5 \mathrm{~min}$ (3,5-dimethyl-benzaldehyde, $15.6 \%$ relative abundance). Several small peaks were also evident throughout the chromatogram. Of the 19 unique mass signals, putative empirical formulas and identifications were achieved for 16 of these compounds.

\section{DISCUSSION}

Many Terminalia spp. have a history of therapeutic usage to treat microbial infections and numerous recent investigations have reported on their antibacterial properties. ${ }^{32}$ The Australian species T. ferdinandiana has proven to be particularly effective, with growth inhibitory activity reported against a broad panel of bacterial pathogens, ${ }^{17}$ as well as against some bacterial triggers of rheumatoid arthritis ${ }^{14,16}$ and multiple sclerosis. ${ }^{15}$ Furthermore, T. ferdinandiana has also recently been reported to inhibit the proliferation of the gastrointestinal protozoan parasite Giardia duodenalis ${ }^{13}$ indicating its therapeutic potential against both prokaryotic and eukaryotic pathogens. Interestingly, whilst inhibition of $B$. anthracis growth was not evaluated in any of the previous studies, one recent study reported potent growth inhibition of the related bacterial species B.cereus, with MIC values as low as approximately $100 \mu \mathrm{g} / \mathrm{mL} .{ }^{17}$ B. cereus is very closely related to $B$. anthracis with $>99 \% 16 \mathrm{~S}$ RNA gene sequence homology. ${ }^{33}$ Indeed, some bacterial taxonomonists believe that $B$. anthracis, B. cereus, B. thuringiensis, B. mycoides, B. pseudomycoides and $B$. weinstephanensis should be classified as a single species under current standards ( $>97 \% 16 \mathrm{~S}$ rRNA sequence homology) and are only classified as separate species as a result of the different diseases that they cause. $^{34-36}$ Therefore, it is perhaps not surprising that the T. ferdinandiana extracts screened in our study displayed potent growth inhibitory activity towards B. anthracis.

Qualitative GC-MS headspace analysis of the most potent B. anthracis growth inhibitory $T$. ferdinandiana extracts (fruit ethyl acetate and methanolic leaf extracts) identified a number of interesting compounds which may contribute to this activity. The presence of the furan compounds 1-(2-furanyl)-ethanone (Figure 5a) and ethyl 2-(5-methyl-5-vinyl tetra hydrofuran-2-yl) carbonate (Figure $5 b$ ) are particularly note worthy as many furan derivatives are potent inhibitors of bacterial growth. The nitro furans have particularly well studied antimicrobial mechanisms, acting via the inhibition of nucleic acid synthesis. ${ }^{37}$ Similarly, another study reported synthetic furan derivatives (modified by the addition of a rhodanine moiety) to be potent inhibitors of the growth of a panel of 
Table 3: Qualitative GC-MS analysis of the T. ferdinandiana fruit ethyl acetate extract, elucidation of empirical formulas and putative identification of each compound

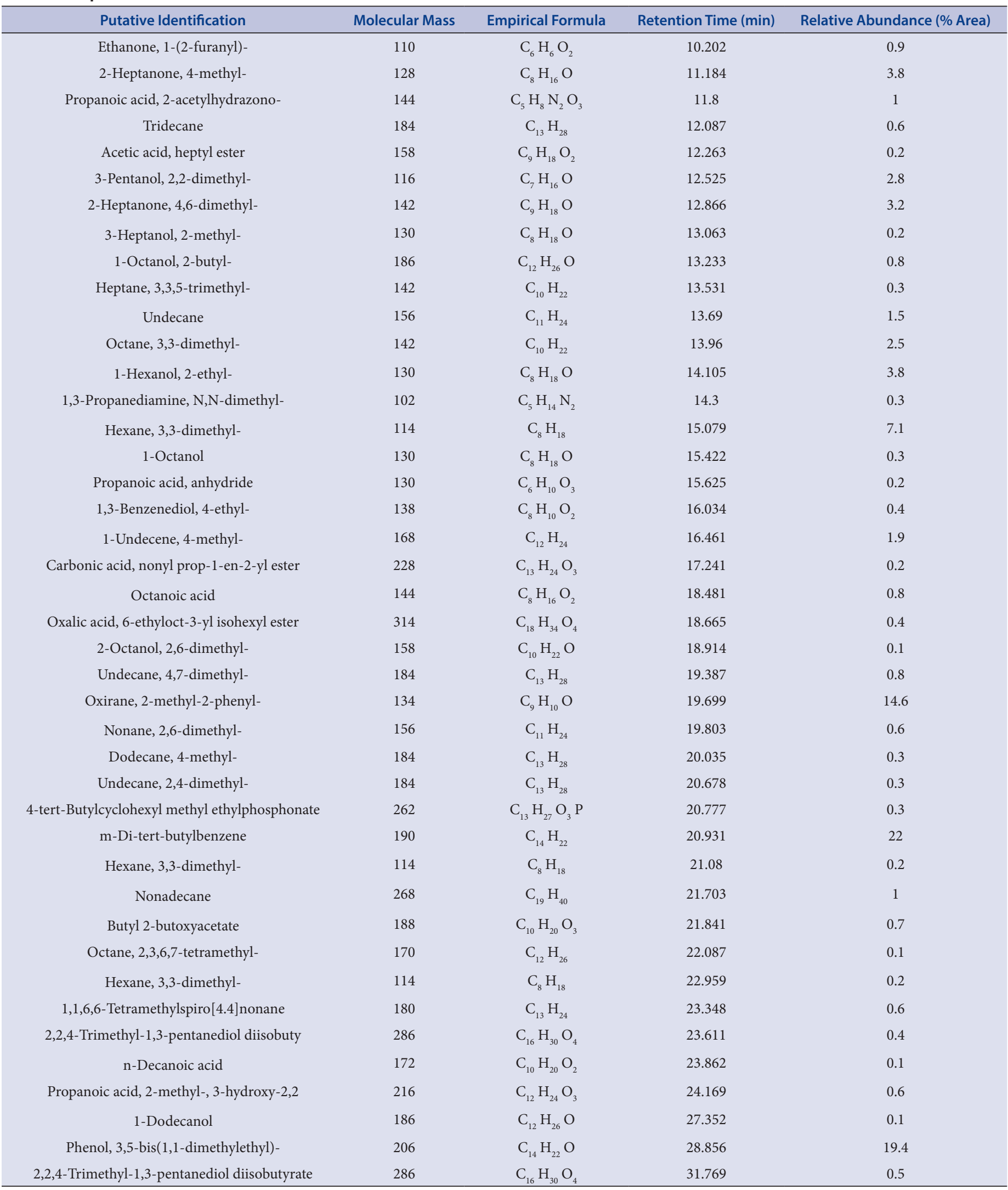

The relative abundance expressed in this table is a measure of the area under the peak expressed as a $\%$ of the total area under all chromatographic peaks. 
Table 4: Qualitative GC-MS analysis of the methanolic T. ferdinandiana leaf extract, elucidation of empirical formulas and putative identification of each compound

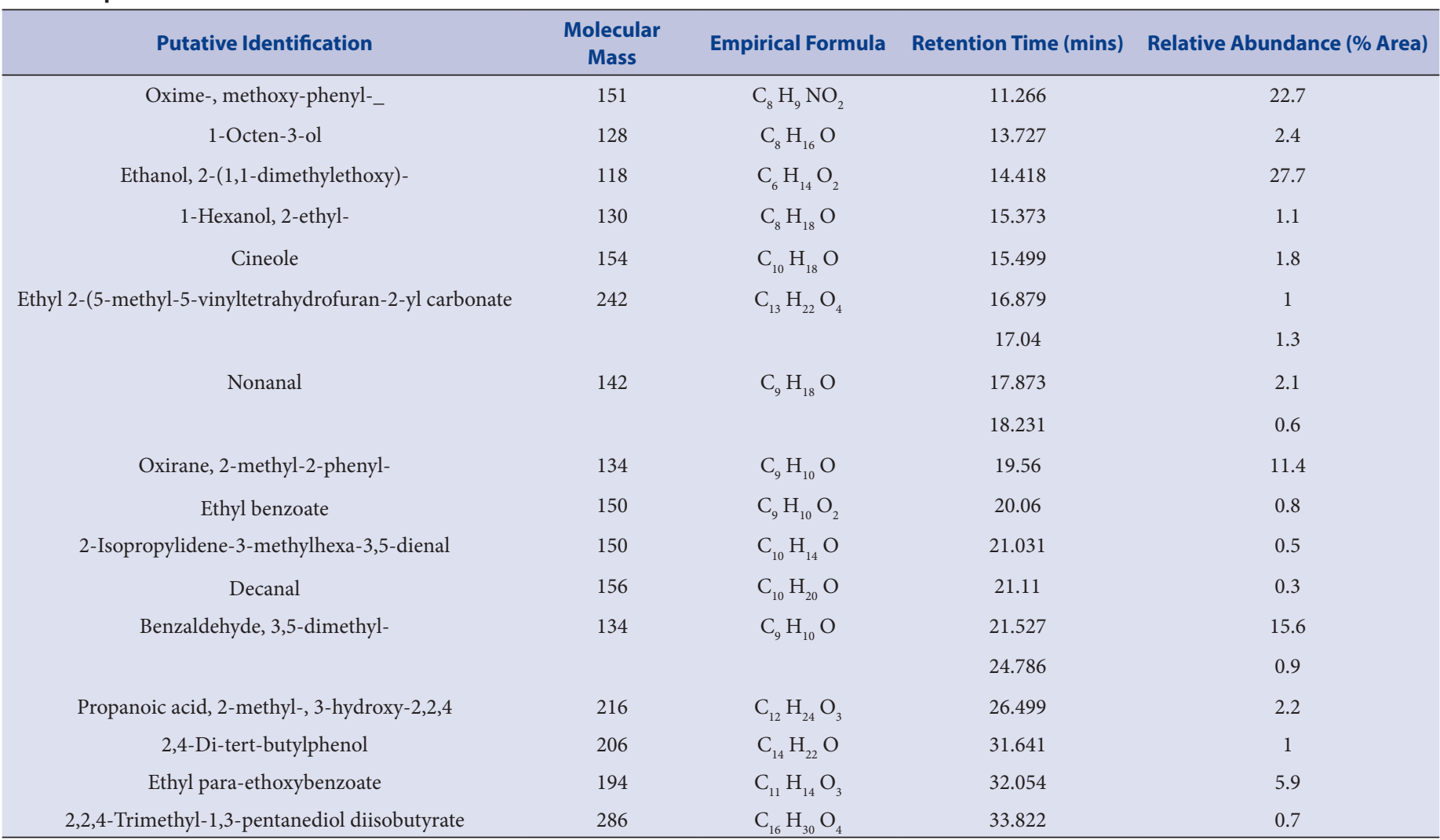

The relative abundance expressed in this table is a measure of the area under the peak expressed as a $\%$ of the total area under all chromatographic peaks.

multidrug resistant bacteria, with MIC values as low as $2 \mu \mathrm{g} / \mathrm{mL}$ against some species. ${ }^{38}$ Whilst we were unable to find reports of anti-bacterial activity for the 2 furan derivatives present in in the T. ferdinandiana extracts, it is possible that they may contribute to the growth inhibitory activities reported in our study.

It is likely that other phytochemical classes also contribute to the growth inhibitory properties of these extracts. Our qualitative phytochemical screening studies indicate that polyphenolics, flavonoids, saponins, and terpenes were present in the T. ferdinandiana extracts. As our study used headspace GC-MS techniques to putatively identify the phytochemical composition of the extracts, many of the mid to higher polarity compounds may have not been identified. Recent studies have reported the LC-MS profiles of similar T. ferdinandiana fruit ${ }^{13,15,16}$ and leaf extracts. ${ }^{14}$ Several features were common to all of these studies. All reported on the diversity of tannins in both the fruit and leaf extracts. Gallic (Figure 5c) and ellagic acids (Figure 5d) and their methylated derivatives, chebulic acid (Figure 5e), galloylpyrogallol (Figure 5f), corilagen (Figure 5g), punicalin (Figure 5h), castalagin (Figure 5i) and chebulagic acid (Figure 5j) were detected in T. ferdinandiana extracts in each of those studies. These tannins have potent, broad spectrum growth inhibitory activity against a variety of bacterial species. ${ }^{32}$ Gallotannins have particularly well reported inhibitory properties. ${ }^{39}$ They function via multiple mechanisms including interacting with both cell surface proteins $^{40,41}$ and through interactions with intracellular enzymes. ${ }^{42}$ Ellagitannins also interact with cellular proteins and induce disruptions in bacterial cell walls. ${ }^{39,41}$

Several recent studies also highlighted the stilbene components of a methanolic T. ferdinandiana fruit extracts. ${ }^{14,15}$ Resveratrol (Figure 5k) and the glycosylated resveratrol derivative piceid (Figure 5l), diethyl- stilbestrol monosulfate (Figure $5 \mathrm{~m}$ ) and combretastatin A1 (Figure 5n) were putatively identified in those studies. Identification of combretastatin A1 was particularly interesting as combretastatins have attracted much recent interest due to their potent ability to block cancer cell progression and induce apoptosis by binding intracellular tubulin, thereby disrupting microtubule formation..$^{43}$ Whilst we were unable to find accounts of bacterial growth inhibition of combretastatin A1 in the literature, the growth inhibition of Staphylococcus aureus, Streptococcus pneumoniae, Escherichia coli and Neisseria gonorrhoeae by several synthetic combretastatins (and synthetic resveratrol analogues) have been reported. ${ }^{44}$ Therefore, it is likely that the $T$. ferdinandiana extract stilbene components may also contribute to the $B$. anthracis growth inhibition noted in our study.

Several important terpenoids have also been reported in T. ferdinandiana extracts in recent studies. ${ }^{15}$ Monoterpenoids were particularly prevalent, with isomyocorene, cineol, cuminol, camphor, iso-menthol reported in T. ferdinandiana fruit ethyl acetate extract examined in that study. Notably, cineole was also putatively identified in the anti- B. anthracis leaf methanolic extract examined in our study. Many of these terpenoids have potent broad spectrum antibacterial activity ${ }^{45}$ and therefore may contribute to the $B$. anthracis growth inhibition reported in our study. Interestingly, several of these monoterpenes have also been reported to suppress NF- $\mathrm{kB}$ signalling (the major regulator of inflammatory diseases) ${ }^{46-49}$ Thus, the terpene components may have a pleuripotent mechanism in blocking anthrax, by inhibiting the growth of the causative bacterium, as well as relieving the downstream inflammatory symptoms evident with the most common (cutaneous) form of the disease.

With the exception of the T. ferdinandiana ethyl acetate leaf extract, the findings reported here demonstrate that the T. ferdinandiana extracts 


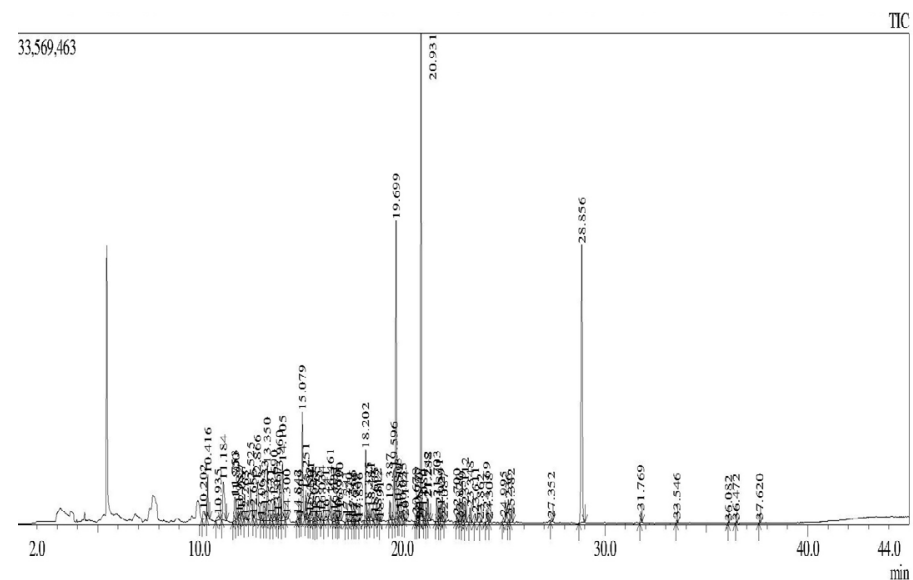

Figure 3: Head space gas chromatogram of $0.5 \mu \mathrm{L}$ injections of T. ferdinandiana ethyl acetate fruit extract. The extract were dried and resuspended in methanol for analysis.

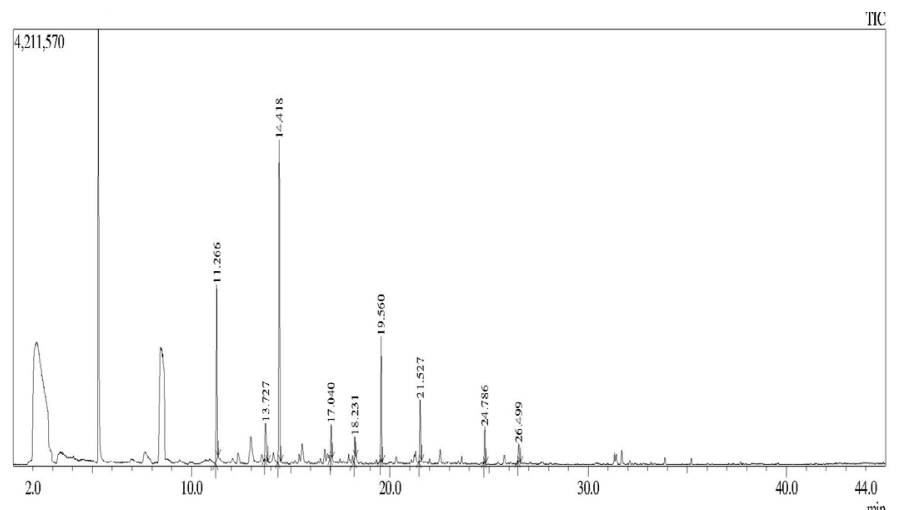

Figure 4: Head space gas chromatogram of $0.5 \mu \mathrm{L}$ injections of methanolic $T$. ferdinandiana leaf extract. The extract were dried and resuspended in methanol for analysis.

a<smiles>C1=C(c2ccccc2)CCC1</smiles>

b
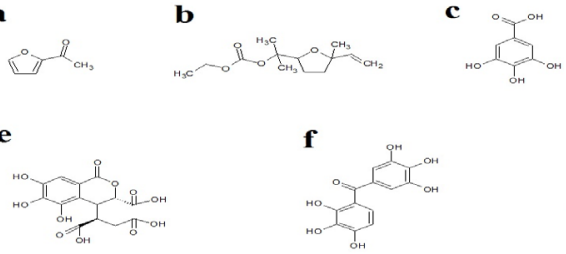

$\mathbf{h}$
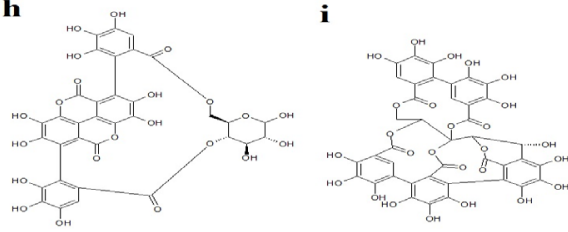

$\mathbf{j}$

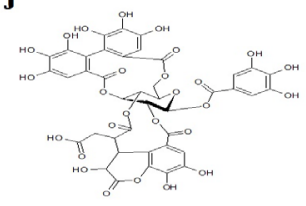

$\mathbf{k}$
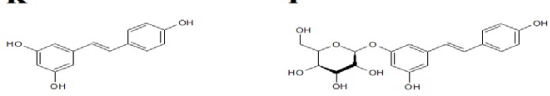

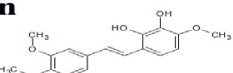

$\mathrm{H}^{3} \mathrm{C}^{-} \mathrm{O}^{2}$

Figure 5: Chemical structures of (a) 1-(2-furanyl)-ethanone, (b) ethyl 2-(5-methyl-5-vinyltetrahydrofuran-2-yl) carbonate, (c) gallic acid, (d) ellagic acid; (e) chebulic acid, (f) galloyl pyrogallol, (g) corilagen, (h) punicalin, (i) castalagin, (j) chebulagic acid, (k) resveratrol, (I) piceid, (m) diethylstilbestrol monosulfate, $(n)$ combretastatin A1. were nontoxic towards Artemia franciscana nauplii, with $\mathrm{LC}_{50}$ values substantially $>1000 \mu \mathrm{g} / \mathrm{mL}$. Extracts with $\mathrm{LC}_{50}$ values $>1000 \mu \mathrm{g} / \mathrm{mL}$ towards Artemia nauplii are defined as being nontoxic. ${ }^{31}$ Even the ethyl acetate leaf extract which induced significant mortality was deemed low to moderate toxicity due to its moderate $\mathrm{LC}_{50}$ value. Whilst our preliminary toxicity studies indicate that these extracts may be safe for use as $B$. anthracis growth inhibitors, studies using human cell lines are required to further evaluate the safety of these extracts. Furthermore, whilst the results of our study are promising, it must be noted that the growth inhibitory studies screened against vegetative cells. As Bacillus spp. are spore formers, further studies are required to determine whether extracts with $B$. anthracis growth inhibitory activity also affect bacterial growth from the spores.

\section{CONCLUSION}

The results of this study demonstrate the potential of $T$. ferdinandiana in the inhibition of B. anthracis growth. The fruit ethyl acetate and methanolic leaf extracts were particularly potent growth inhibitors. Further investigations aimed at the purification of the bioactive components are needed to assess the mechanisms of action of these agents.

\section{ACKNOWLEDGEMENTS}

Financial support for this work was provided by the Environmental Futures Research Institute and the School of Natural Sciences, Griffith University, Australia. The authors are most grateful to David Boehme of Wild Harvest, Northern Territory, and Australia for providing the T. ferdinandiana fruit pulp and leaves used in these studies.

\section{CONFLICTS OF INTEREST}

The authors report no conflicts of interest.

\section{ABBREVIATIONS}

DMSO: Dimethyl sulfoxide, $\mathbf{L C}_{50}$ : The concentration required to achieve $50 \%$ mortality, MIC: minimum inhibitory concentration, PYE: peptone yeast extract.

\section{REFERENCES}

1. Schantz PM. Parasitic zoonoses in perspective. International Journal for Parasitology. 1991;21(2):161-170. http://dx.doi.org/10.1016/0020-7519(91)90006-S

2. Weber DJ, Rutala WA. Risks and prevention of nosocomial transmissionof rare zoonotic diseases. Healthcare Epidemiology. 2001;32(3):446-456.

3. Jones KE, Patel NG, Levy MA, et al. Global trends in emerging infectious diseases. Nature. 2008;451(7181):990-993. http://dx.doi.org/10.1038/nature06536; PMid:18288193

4. Han CS, Xie G, Challacombe JF, et al. Pathogenomicsequence analysis of Bacillus cereus and Bacillus thuringiensisisolates closely related to Bacillus anthracis. Journal of Bacteriology. 2006;188(9):3382-3390. http://dx.doi.org/10.1128/JB. 188.9.3382-3390.2006 ; PMid:16621833 PMCid:PMC1447445.

5. Wright $\mathrm{MH}$, Greene $\mathrm{AC}$, Cock IE. Inhibition of Bacillus anthracis growth by Australian native plants traditionally used as antibacterial medicines. Pharmacognosy Journal. 2015; DOI: 10.5530/pj.2015.6.13. http://dx.doi.org/10.5530/ pj.2015.6.13

6. Okinaka RT, Cloud K, Hampton O, et al. Sequence and organization of pXO1, the large Bacillus anthracis plasmid harboring the anthrax toxin genes. Journal of Bacteriology. 1999;181(20):6509-6515. PMid:10515943 PMCid:PMC103788.

7. Pilo P, Frey J. Bacillus anthracis: Molecular taxonomy, population genetics, phylogeny andpatho-evolution. Infection, Genetics and Evolution. 2011;11(6):12181224. http://dx.doi.org/10.1016/j.meegid.2011.05.013; PMid:21640849.

8. Bartlett JG, Inglesby TV, Borio L. Management of Anthrax. Clinical Infectious Diseases. 2002;35:851-858. http://dx.doi.org/10.1086/341902 ; PMid:12228822.

9. Wright $\mathrm{MH}$, Matthews B, Greene AC, et al. Growth inhibition of the zoonotic bacteria Bacillus anthracis by high antioxidant Australian plants: New leads for the prevention and treatment of anthrax. Pharmacognosy Communications. 2015;5(3):173-189. http://dx.doi.org/10.5530/pc.2015.3.3

10. Mohanty $S$ and Cock IE. The chemotherapeutic potential of Terminalia ferdinandiana: Phytochemistry and bioactivity. Pharmacognosy Reviews. 
2012;6(11):29-36. http://dx.doi.org/10.4103/0973-7847.95855; PMid:22654402 PMCid:PMC3358965.

11. Netzel M, Netzel G, Tian Q, et al. Native Australian fruits - a novel source of antioxidants for food. Innovative Food Science and Emerging Technologies. 2007;8(3):339-346. http://dx.doi.org/10.1016/j.ifset.2007.03.007

12. Konczak I, Maillot F, Dalar A. Phytochemical divergence in 45 accessions of Terminalia ferdinandiana (Kakadu plum). Food Chemistry. 2014;151:248-256. http://dx.doi.org/10.1016/j.foodchem.2013.11.049; PMid:24423529.

13. Rayan P, Matthews B, McDonnell PA, et al. Terminalia ferdinandiana extracts as inhibitors of Giardia duodenalis proliferation: a new treatment for giardiasis. Parasitology Research. 2015;114(7):2611-2620. http://dx.doi.org/10.1007/s00436-0154465-4; PMid:25876047.

14. Courtney R, Sirdaarta J, Matthews B, et al. Tannin components and inhibitory activity of Kakadu plum leaf extracts against microbial triggers of autoimmune inflammatory diseases. Pharmacognosy Journal. 2015;7(1):18-31. http://dx.doi. org/10.5530/pj.2015.7.2

15. Sirdaarta J, Matthews B, White A, et al. GC-MS and LC-MS analysis of Kakadu plum fruit extracts displaying inhibitory activity against microbial triggers of multiple sclerosis. Pharmacognosy Communications 2015:5(2):100-115 http://dx.doi.org/10.5530/pc.2015.2.2

16. Sirdaarta J, Matthews B, Cock IE. Kakadu plum fruit extracts inhibit growth of the bacterial triggers of rheumatoid arthritis: Identification of stilbene and tannin components. Journal of Functional Foods. 2015;17:610-620. http://dx.doi. org/10.1016/j.jff.2015.06.019.

17. Cock IE, Mohanty S. Evaluation of the antibacterial activity and toxicity of Terminalia ferdinandianafruit extracts. Pharmacognosy Journal. 2011;3(20):72-79. DOI: 10.5530/pj.2011.20.14 http://dx.doi.org/10.5530/pj.2011.20.14.

18. Kalt FR, Cock IE. Gas chromatography-mass spectroscopy analysis of bioactive Petalostigma extracts: Toxicity, antibacterial and antiviral activities. Pharmacognosy Magazine. 2014:10(37 Supp):S37-S49. http://dx.doi.org/10.4103/09731296.127338; PMid:24914307 PMCid:PMC4047571.

19. Sautron C, Cock IE. Antimicrobial activity and toxicity of Syzygium australe and Syzygium leuhmannii fruit extracts. Pharmacognosy Communications. 2014;4(1):53-60. http://dx.doi.org/10.5530/pc.2014.1.8.

20. Vesoul J, Cock IE. The potential of Bunya nut extracts as antibacterial functional foods. Pharmacognosy Communications. 2012;2(1):72-79. http://dx.doi. org/10.5530/pc.2012.1.13.

21. Arkhipov A, Sirdaarta J, Rayan $P$, et al. An examination of the antibacterial, antifungal, anti-Giardial and anticancer properties of Kigeliaafricana fruit extracts. Pharmacognosy Communications. 2014;4(3):62-76. http://dx.doi. org/10.5530/pc.2014.3.7

22. Hart C, Ilanko P, Sirdaarta J, et al. Tasmannia stipitata as a functional food/natural preservative: Antimicrobial activity and toxicity. Pharmacognosy Communications. 2014; 4(4): 33-47. DOI: 10.5530/pc.2014.4.4.

23. Jamieson N, Sirdaarta J, Cock IE. The anti-proliferative properties of Australian plants with high antioxidant capacities against cancer cell lines. Pharmacognosy Communications. 2014;4(4):71-82.

24. Cock IE, van Vuuren SF. Anti-Proteus activity of some South African medicinal plants: their potential for the prevention of rheumatoid arthritis. Inflammopharmacology. 2014;22(1):23-36. DOI 10.1007/s10787-013-0179-3 http://dx.doi. org/10.1007/s10787-013-0179-3

25. Winnett $\mathrm{V}$, Boyer $\mathrm{H}$, Sirdaarta J, et al. The potential of Tasmannia lanceolata as a natural preservative and medicinal agent: Antimicrobial activity and toxicity. Pharmacognosy Communications. 2014;4(1):42-52. http://dx.doi.org/10.5530/ pc.2014.1.7.

26. Kalt FR, Cock IE. The medicinal potential of Australian native plants from Toohey Forest, Australia. The South Pacific Journal of Natural Science. 2011;28(1):41-47. http://dx.doi.org/10.1071/SP10003.

27. Cock IE, van Vuuren SF. The potential of selected South African plants with antiKlebsiella activity for the treatment and prevention of ankylosing spondylitis Inflammopharmacology. 2014;23(1):21-25. DOI 10.1007/s10787-014-0222-z http://dx. doi.org/10.1007/s10787-014-0222-z.

28. Cock IE. Antimicrobial activity of Acacia aulacocarpa and Acacia complanta methanolic extracts. Pharmacognosy Communications. 2012;2(1):66-71. http:// dx.doi.org/10.5530/pc.2012.1.12.

29. Cock IE. Assessment of the toxicity of selected Australian native plant extracts using the Artemia franciscana nauplii bioassay. Internet Journal of Toxicology. 2008;5:2.

30. Ruebhart DR, Wikramasinghe WA, Cock IE. Protective efficacy of the antioxidants vitamin $\mathrm{E}$ and Trolox against Microcystis aeruginosa and microcystin-LR in Artemia franciscana nauplii. Journal of Toxicology and Environmental Health Part A. 2009; 72(24):1567-1575. http://dx.doi.org/10.1080/15287390903232459; PMid:20077231.

31. Cock IE, Ruebhart DR. Comparison of the brine shrimp nauplii bioassay and the ToxScreen-II test for the detection of toxicity associated with Aloe vera (Aloe barbadensis Miller) leaf extract. Pharmacognosy Research. 2009; $1(2): 98-101$

32. Cock IE. The medicinal properties and phytochemistry of plants of the genus Terminalia (Combretaceae). Inflammo pharmacology. 2015; DOI 10.1007/ s10787-015-0246-z http://dx.doi.org/10.1007/s10787-015-0246-z .

33. Maughan $H$, Van der Auwera G. Bacillus taxonomy in the genomic era finds phenotypes to be essential though often misleading. Infection, Genetics and Evolution. 2011;11(5):789-797. http://dx.doi.org/10.1016/j.meegid.2011.02.001; PMid:21334463.

34. Tourasse NJ, Helgason E, Okstad OA et al. The Bacillus cereus group: nove aspects of population structure and genome dynamics. Journal of Applied Microbiology. 2006;101(3):579-593. http://dx.doi.org/10.1111/j.1365-2672.2006.03087.x PMid:16907808.

35. Priest FG, Barker M, Baillie LW, et al. Population structure and evolution of the Bacillus cereus group. Journal of Bacteriology. 2004;186(23):79597970. http://dx.doi.org/10.1128/JB.186.23.7959-7970.2004; PMid:15547268 PMCid:PMC529064

36. Rasko DA, Altherr MR, Han CS, et al Genomics of the Bacillus cereus group of organisms. FEMS Microbiology Reviews. 2005;29(2):303-329 http://dx.doi.org/10.1016/j.femsre.2004.12.005. http://dx.doi.org/10.1016/j. fmrre.2004.12.005; PMid:15808746.

37. Munoz-Davila MJ. Role of old antibiotics in the era of antibiotic resistance. Highlighted nitrofurantoin for the treatment of lower urinary tract infections. Antibiotics. 2014;3(1):39-48. http://dx.doi.org/10.3390/antibiotics3010039. PMid:27025732 PMCid:PMC4790343

38. Che J, Zheng CJ, Song MX et al. Synthesis and antibacterial evaluation of furan derivatives bearing a rhodanine moiety. Medicinal Chemistry Research. 2014;23(1):426-435. http://dx.doi.org/10.1007/s00044-013-0648-7.

39. Buzzini $P$, Arapitsas $P$, Goretti M, et al. Antimicrobial activity of hydrolysable tannins.Mini-Reviews Med Chem. 2008;8(12):1179-1187. http://dx.doi.org/10.2174/ 138955708786140990.

40. Wolinsky LE, Sote EO. Isolation of natural plaque-inhibiting substances from Nigerian chewing sticks. Caries Res. 1984;18(3):216-225. http://dx.doi. org/10.1159/000260768

41. Hogg SD, Embery G. Blood-group-reactive glycoprotein from human saliva interacts with lipoteichoic acid on the surface of Streptococcus sanguiscells. Arch Oral Biol. 1982;27(3):261-268. http://dx.doi.org/10.1016/00039969(82)90060-7.

42. Wu-Yuan CD, Chen CY, Wu RT. Gallotannins inhibit growth, watersolubleglucan synthesis, and aggregation of Streptococci mutans. J Dental Res. 1988;67(1):51 55. http://dx.doi.org/10.1177/00220345880670011001.

43. Dark GG, Hill SA, Prise VE, et al. Combretastatin A-4, an agent that displays potent and selective toxicity toward tumor vasculature. Cancer Res, 1997;57(10):1829-34. PMid:9157969.

44. Pettit RK, Pettit GR, Hamel E, et al. E-Combretastatin and E-resveratrol structural modifications: Antimicrobial and cancer cell growth inhibitory $\beta-E-$ nitrostyrenes. Bioorganic and Medicinal Chemistry. 2009;17(18):6606-6612. http://dx.doi.org/10.1016/j.bmc.2009.07.076 ; PMid:19709889.

45. Cock IE. The phytochemistry and chemotherapeutic potential of Tasmannia lanceolata (Tasmanian pepper): A review. Pharmacognosy Communications. 2013;3(4):13-25.

46. Salminen A, Lehtonen M, Suuronen T, et al.Terpenoids: Natural inhibitors of NF-kB signalling with anti-inflammatory and anticancer potential. Cell Molec Life Sci. 2008;65(19):2979-99. http://dx.doi.org/10.1007/s00018-008-8103-5; PMid:18516495.

47. Lu XG, Zhan LB, Feng BA, et al. Inhibition of growth and metastasis of human gastric cancer implanted in nude mice by d-limonene. World JGastroenterol. 2004;10(14):2140-4. http://dx.doi.org/10.3748/wjg.v10.i14.2140 PMCid:PMC4572353.

48. Crowell PL. Prevention and therapy of cancer by dietary monoterpenes. J Nutr. 1999;129(3):775S-8S. PMid:10082788.

49. Zhou JY, Tang FD, Mao GG, et al. Effect of a-pinene on nucleartranslocation of NF-kB in THP-1 cells. ActaPharmacol Sin. 2004:25(4):480-4. PMid:15066217. 
GRAPHICAL ABSTRACT

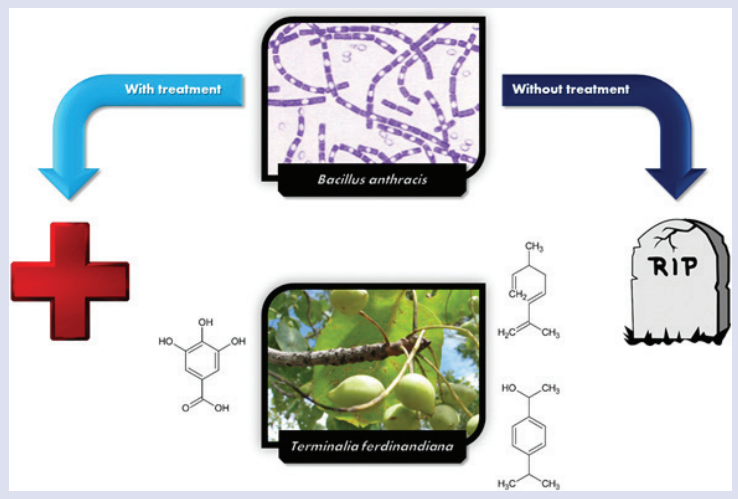

\section{HIGHLIGHTS OF PAPER}

- T. ferdinandiana fruit and leaf extractswere inhibitors of Bacillus anthracis growth.

- The fruit ethyl acetate and methanolic leaf extracts were particularly potent growth inhibitors with MIC's of 451 and $377 \mu \mathrm{g} / \mathrm{mL}$ respectively.

- All inhibitory extracts were non-toxic in the Artemia nauplii assay.

- GC-MS headspace profiling of the inhibitory extracts revealed distinct phytochemical profiles for the fruit and leaf extracts.

- Phytochemical profiling highlighted several nonpolar compounds as potentially contributing to the $B$. anthracis growth inhibitory activity.

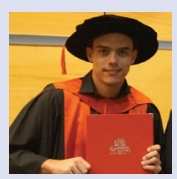

\section{AUTHOR PROFILE}

Dr Wright: Received his PhD in 2014, for his work investigating the manganese reduction and oxidation characteristics of environmental bacteria. He is currently a postdoctoral researcher at Griffith University, Australia, where he is working on several projects both in the areas of geomicrobiology and pharmocognosy. His present research interests are the use of biogenic manganese oxides in the bioremediation of metal-contaminated sites as well as the use of Australian native plants in the treatment and prevention of various pathogenic bacteria.

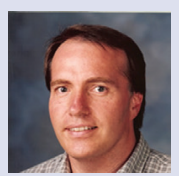

Dr Anthony Greene: Is a senior lecturer and researcher at Griffith University, Brisbane Australia. He obtained his PhD in Microbiology from the University of New South Wales and focuses on extreme environments, bioremediation and geomicrobiology. His specific interests include the microbial ecology of thermophilic, saline and alkaliphilic environments and the mechanisms and industrial potential of extremophilic bacteria contained therein.

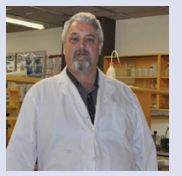

Dr lan Cock: Leads a research team in the Environmental Futures Research Institute and the School of Natural Sciences at Griffith University, Australia. His research involves bioactivity and phytochemical studies into a variety of plant species of both Australian and international origin, including Aloe vera, South Asian and South American tropical fruits, as well as Australia plants including Scaevolaspinescens, Pittosporum phylliraeoides, Terminalia ferdinandiana (Kakadu plum), Australian Acacias, Syzygiums, Petalostigmas and Xanthorrhoea johnsonii (grass trees). This range of projects has resulted in nearly 200 publications in a variety of peer reviewed journals.

Cite this article : Wright MH, Sirdaarta J, White A, Greene CA, Cock IE. GC-MS headspace analysis of Terminalia ferdinandiana fruit and leaf extracts which inhibit Bacillus anthracis growth. Pharmacog J. 2017;9(1):73-82. 